\title{
The Development of Audio Visual Media on Volleyball Forearm Pass Technique for Senior High School Students
}

\author{
Ade Satria Hasibuan \\ Department of Physics Education \\ Postgraduate School Univeritas \\ Negeri Medan \\ Medan. Indonesia \\ adesatriahasibuan26@gmail.com
}

\author{
Tarsyad Nugraha \\ Lecturer of Physics Education \\ Postgraduate School Univeritas \\ Negeri Medan \\ Medan. Indonesia
}

\author{
Amir Supriadi \\ Lecturer of Physics Education \\ Postgraduate School Univeritas \\ Negeri Medan \\ Medan. Indonesia
}

\begin{abstract}
This study aims to produce an audio visual media on volleyball forearm pass technique for senior high school students. The method used is Research and Development (R\&D) which is using Dick and Carey development design. It was adapted to this research become four stages, namely (1) needs analysis stage was conducted by literature study, that was by conducting field study or observation; (2) design product stage which was divided into three sections including: preparation of volly forearm pass technique materials, setting up storyboards, video capture and video editing; (3) product evaluation stage, the product will be evaluated by a learning design expert, physical education specialist, and software specialist (4) and final product steps form a feasible audio visual media on volleyball forearm pass technique for senior high school students. (Abstract)
\end{abstract}

Keywords - Audio Visual Media; Volleyball Forearm Pass; Physics Education

\section{INTRODUCTION}

Learning is a process of interaction between students and their environment so that there is a change in behavior towards a better direction. In other words, good communication is needed in the delivery of information. The information is in the form of material content from certain learning subjects delivered by the teacher to students through a particular medium. Today, students not only act as recipients of the message but turn around as function of storing messages so that communication is a two-way communication. A learning activity requires proper learning media to improve student learning outcomes.

The rapid development of computer technology has been successful in the world of education, seen with the use of computers as one of the interactive learning media to assist in the delivery of learning material in the form of multimedia for students who are educating and entertaining for students (Saputra, 2014).

In physical education, teachers are expected to teach basic movement skills, game and sports techniques and strategies, internalization of values (sportsmanship, honesty, cooperation, etc.) as well as a healthy lifestyle. There is no education that has no pedagogical goals, and there is no complete education without physical education, because physical education is the basis for humans to do sports activities. So, physical education is all the fun activities of the movement and makes students become active, creative, innovative, sportive and habituation to healthy lifestyles (Haryanto, 2015).

Some problems found in sports learning, including the first, the learning resources for students are still limited, that is only from teachers. Thus, students have not been motivated to seek information and only rely on information provided by the teacher during the implementation of learning in the classroom and in the field. whereas in reality learning not all subject matter can be delivered completely by the teacher considering the time given to the teacher is so short. The theory given is mostly delivered outside the classroom or in the field and without using any media so that the information provided is only from sports teachers.

Second, the use of school facilities as a learning medium that is not optimal due to lack of optimization of facilities that make students only fixated on practice in the field and override the subject matter taught, lack of interest of students in volleyball game material because the learning media used by teachers is limited to books and student worksheets and no other media to support learning.

Third, the lack of interest of students to listen to the delivery of theory and practice volleyball games. Some think that this game has often been done so that they no longer need to listen to the material presented by the teacher and they feel bored with the monotonous learning model. As well as looking indifferent to students who consider volleyball games they have often done so they do not need to listen to the teacher's explanation again. In reality, there are still many students who are less active in the field due to boredom with the same movement and repetition.

Fourth, there are students who have not been able to perform basic techniques properly especially under passing. 
The problem that occurs when implementing volleyball learning, students doing under-passing both to friends and heading to the area against the ball often do not arrive or deviate. Then, students make passing passing carelessly which is important the ball crosses the net and falls in the opponent's area. Even though downward passing is the basic technique of volleyball games that are quite important. The sports facilities and infrastructure that can be used for volleyball learning activities are field, volley ball and net.

So that the development of learning media is needed that can help overcome these problems. Seeing from these limitations, the appropriate learning media to be developed are interactive learning media in the hope that learning is more attractive to students and not monotonous, and ultimately it is expected to increase students' movement skills in playing volleyball, especially in achieving good basic techniques.

The advantages of interactive learning media have the ability to broaden students' knowledge knowledge by displaying information, new knowledge and learning experiences that are difficult to obtain directly by students. This media is also able to stimulate interest in learning through the presentation of interesting images and information (Pribadi, 2004).

The results of the research conducted by Putro (2013) stated that the development of basic volleyball technique learning media for junior high school students with effectiveness results obtained an average pretest score of 5.4 and a posttest score of 8.6. Besides learning media, the focus of the research is the use of learning models. One learning model that can be applied in mastering the skills of volleyball under-passing techniques is a direct learning model. And also Satrianto's research (2014) that direct learning models with modification of mini volleyball have a better impact on improving learning outcomes that is equal to $58.67 \%$ compared to control group learning by $25.37 \%$.

The conditions that have been described indicate the need for alternative learning media to train and stimulate teachers to be more effective and competent in using learning media. So that researchers are interested in conducting research on developing video learning of passing techniques in volleyball games based on direct learning models in accordance with the 2013 curriculum.

The formulation of the problem in the research is how the development of audio visual media on volleyball forearm pass technique for senior high school students.

\section{METHOD}

Population in the study of all students XI SMA / MA in the city of Medan. Cluster random sampling technique sample. According to Sugiyono (2003), techniques in this world cannot consist of individuals, or consist of groups or groups. The research sample at the testing stage iss students of XI classes in SMA Swasta Dharmawangsa Medan consisting of two classes, first as an experimental class using developed products and both classes without using products that only used conventional learning.
Validators of the products that have been developed are two lecturers with the last education of S3 in the Olahrag Education Program of Medan State University with a minimum tenure of 10 years.

The Dick \& Carey development stage was adapted into this development research into 4 stages. The researcher tried to adjust the steps for developing Dick \& Carey learning with the step of developing a video of learning passing techniques in volleyball games based on direct learning models in accordance with the 2013 curriculum as well as those presented in theoretical studies. The four steps include needs analysis, product desain, evaluation, and final produk steps.

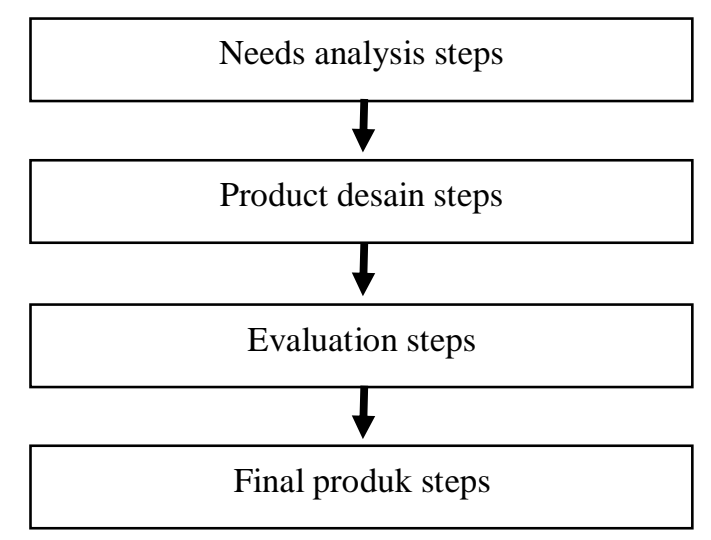

Fig 1. Development Flow (modificated by Dick \& Carey)

The instrument used to collect data from expert evaluations is in the form of a questionnaire. Questionnaires used instruments used to collect data from expert evaluation and trials. Questionnaires used for expert validation in the form of a number of aspects that must be worthy of their feasibility. Validation of experts who will conduct assessments are material experts and media experts.

\section{RESULTS}

\section{A. Needs Analysis Steps}

At this stage the aim is to find out how to learn volleyball passing in high school. This stage of needs analysis is carried out through observation, interviews, and distributing questionnaires to the needs analysis of the health teacher. So what is needed by volleyball passing learning is the availability of audio visual media on volley ball forearm pass technique for senior high school students.

\section{B. Product Desain Steps}

At this stage, several components are needed in making audio visual media (video). In designing learning video, researchers used a camera that was used to record volley ball forearm pass technique. The video recordings are then processed in such a way by using Movie Maker software. The researcher prepares the storyboard aims to assist in making audio visual media (video) in the form of a series of sketches that are made in a rectangle that describes a sequence of 
elements proposed for media applications. Furthermore, the preparation of the lesson material was prepared and included in each frame called screen mapping, using Macromedia Flash software. 8. And then, combine and synergize media elements, namely text, photos, music, and videos into an interactive learning of audio visual media.

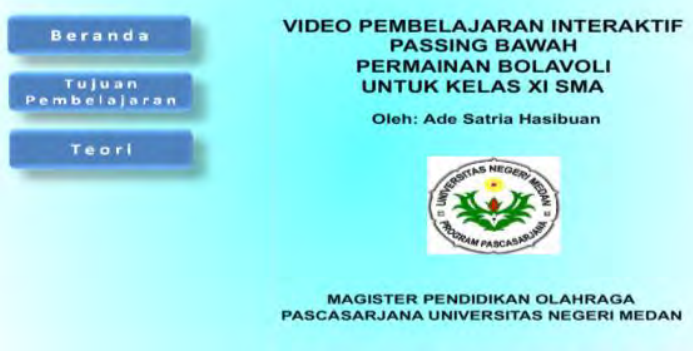

Fig 2. The home page of product developed

For the second slide contains the learning objectives. It is aimed to let the students know the learning objective that will be achieved in the process of learning by using this audio visual media on volley ball forearm pass technique. The learning objective consist o three, there are first students can understand the hand position on volley ball forearm pass technique, second students can undestrand foot position on volley ball forearm pass technique, and third students can practice volley ball forearm pass technique.

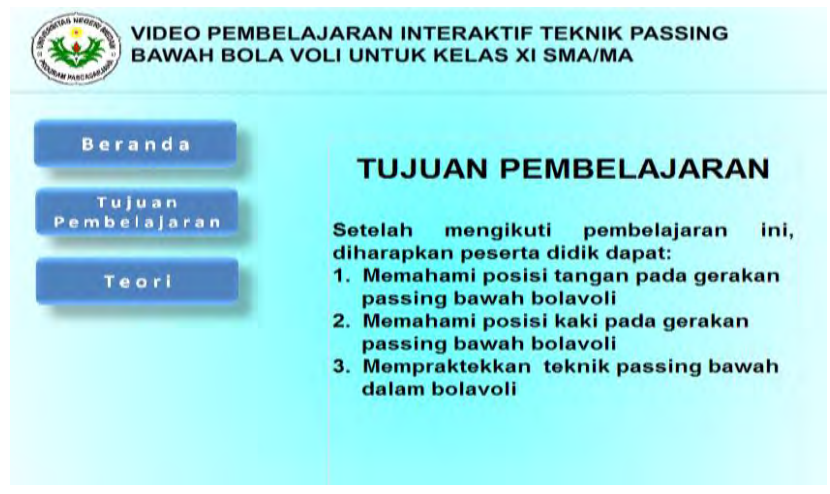

Fig 3. The learning objective view

The theory view consists of the understanding of volley ball, the understanding of forearm pass, forearm pass technique, and the volley ball forearm pass technique video as shown in the figures.

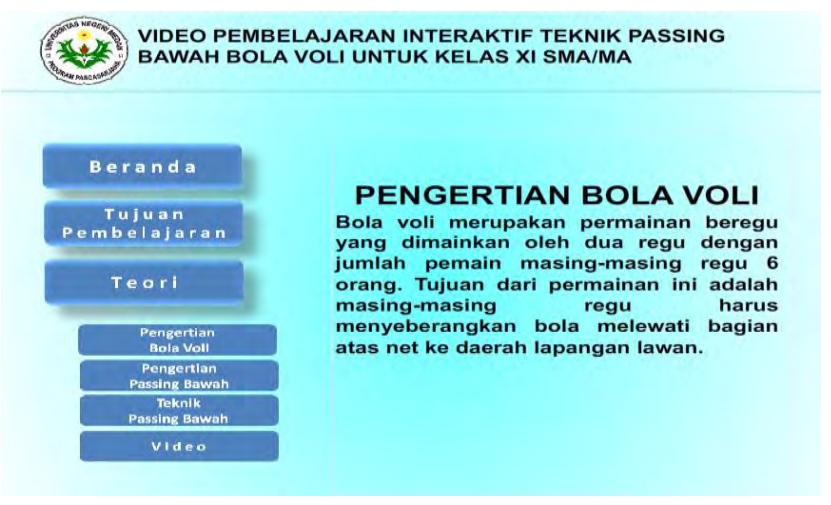

Fig 4. The theory view of the understanding of volley ball VIDEO PEMBELAJARAN INTERAKTIF TEKNIK PASSING BAWAH BOLA VOLI UNTUK KELAS XI SMA/MA

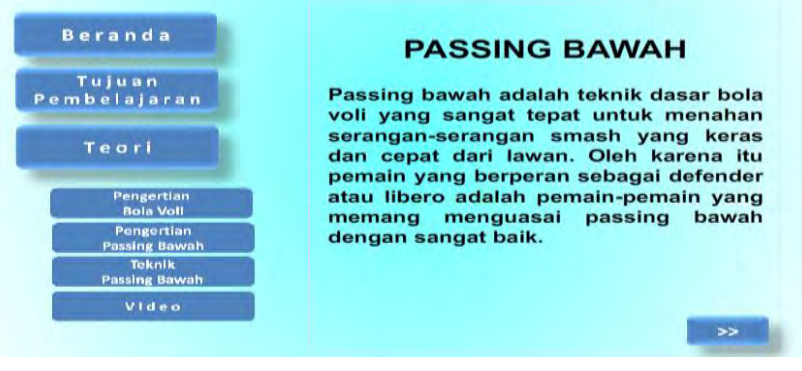

Figure 5. The theory view of the understanding of forearm pass

For the the theory of forearm pass techniques there is a picture of the initial attitude position shown in Fig 6 and the attitude of implementation is shown in Fig 7.

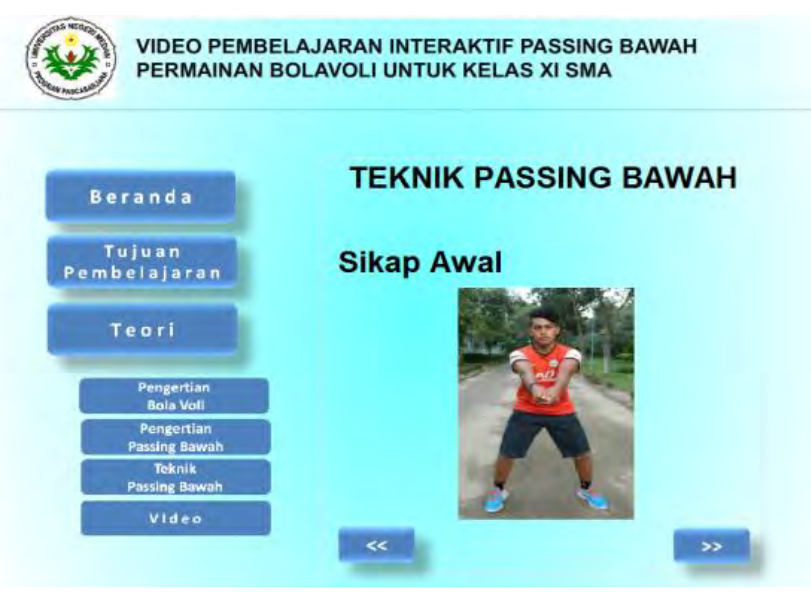

Fig 6 . The theory view of the initial attitude position 
VIDEO PEMBELAJARAN INTERAKTIF PASSING BAWAH PERMAINAN BOLAVOLI UNTUK KELAS XI SMA

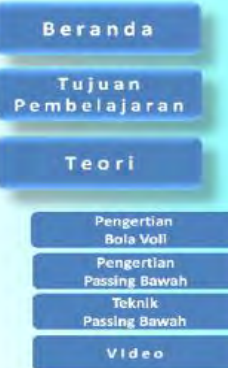

TEKNIK PASSING BAWAH

Sikap Pelaksanaan

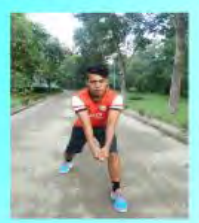

$\ll$

Fig 7. The attitude of implementation

The development of interactive aspect in this product, that is when the user presses the mouse "click" on the hand and foot, the exact position information can be seen in Fig 8 .

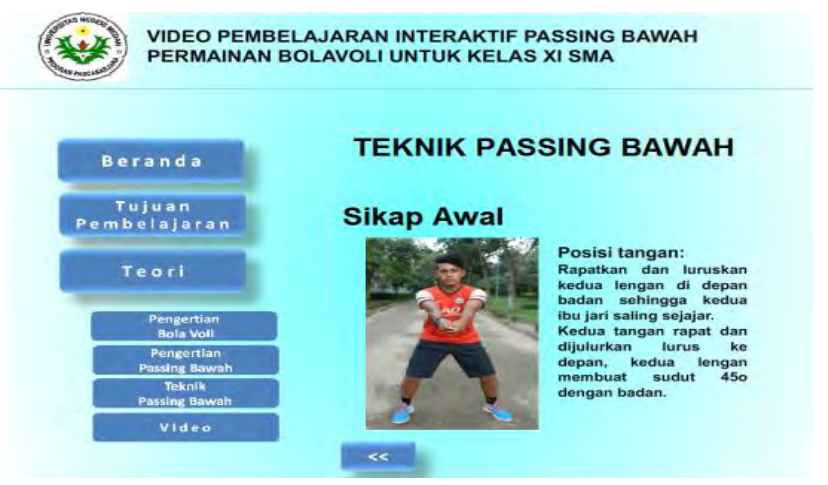

Fig 8 . The information of the initial attitude position

\section{CONCLUSION}

Research and development that has been carried out is a solution to the problems found by researchers when observationwhich are part of the needs analysis phase in schools related to sports learning. As for the presentation in this paper, it only reaches the product design stage in the form of audio visual media on volley ball forearm pass technique for senior high school students.

\section{References}

[1] Andun, Sudijandoko. 2010. Jurnal Pendidikan Jasmani Indonesia. Vol 7 , No 1. Yogyakarta: FIK-UNY

[2] Haryanto, Try Sevita. 2015. Pengembangan Pembelajaran Permainan Bola voli menggunakan Media Interaktif di SMPN 6 Kabupaten Situbondo. Pendidikan Jasmani. Vol 25 No 1

[3] Sofyan, Achmad. 2013. Penerapan Teknologi Pembelajaran Audio Visual terhadap Hasil Belajar Passing Bawah Bola Voli di Sma Negeri 1 Bondowoso. Jurnal Pendidikan Olahraga dan Kesehatan. Vol 1 No 2.

[4] Soni, Nopembri. 2005. Majalah Ilmiah Olahraga. Volume 11, April 2005, TH. XI, No.1. Yogyakarta: FIK-UNY.

[5] Sukintaka. 1992. Teori Bermain. Jakarta: Departemen Pendidikan dan Kebudayaan. Direktorat Jenderal Pendidikan Tinggi. Proyek Pembinaan Tenaga Kependidikan.

[6] Trianto, 2007. Model Pembelajaran Terpadu dalam Teori dan Praktek. Jakarta: Prestasi Pustaka Publisher. 